\title{
Socio-Economic Profiling of Students and its Impact on Learning Outcomes
}

$\underline{\text { https://doi.org/10.3991/ijet.v15i19.14649 }}$

\author{
Abraham Owoseni (四) \\ Covenant University, Ota, Nigeria \\ abraham. owoseni@covenantuniversity.edu.ng \\ Eziyi Ibem \\ University of Nigeria, Nsukka, Nigeria \\ Akunnaya Opoko \\ Covenant University, Ota, Nigeria
}

\begin{abstract}
Every student has a need; and the topmost aspiration of every student is to be self-fulfilled with commendable performance in school. For this aspiration to be achieved, many factors such as the kind of learning environment, teaching methods, socio-economic background, students' motivation amongst others have been found as precursors. In this context, socio-economic characteristics of students include gender, age, class, daily means of transportation to school, geographical location of the school, type of residential accommodation they lived in, and its ownership amongst others. This paper presents findings of a study carried out to measure the impact of socio-economic profiling of students on their academic performance. Quantitative data were collected from twelve sampled secondary schools: nine private owned schools and three public owned schools across three senatorial districts in Lagos State, Nigeria. Multi-stage sampling technique was adopted using a hybrid of three techniques: purposive sampling, quota and random sampling to select the approved schools, group them in quota and final selection of respondents respectively. A total of 674 copies of the questionnaire were administered by hand during the first term of the 2018/2019 academic session. The result identified that amongst several socio-economic characteristics of learners, the geographical location of the school, type of school (private or public) and learning styles of students have more significant impact on students' learning outcomes. This paper recommends that instilling internal motivation in students irrespective of their socioeconomic background can boost their self-esteem and self-actualisation. This will in turn influence their performance favourably.
\end{abstract}

Keywords—Learning, Learning Outcomes, Socio-economic, Students. 


\section{Introduction}

According to the National Bureau of Statistics [1], education in Nigeria is the shared responsibility of the federal, state and local governments. An example is the Lagos State Ministry of Education and State Universal Basic Education Board (SUBEB) at the state level and the Local Government Education Authority (LGEA) at the local government level. For the regulation of the education at the tertiary level and the formation of policy and quality control, the Federal Ministry of Education is at the helm of affairs. Other cadres of schooling are much decentralized under the control of state (secondary) and local (primary) governments. However, opportunity is provided for privately owned schools either as a non-profit, mission school or business. Those owned and managed by the government are often referred to as public schools. In Lagos State, government schools are owned, funded, run and managed by the government, with virtually no autonomy at the school level, with students from families of varying socio-economic backgrounds. Some public schools have been characterized by frequent teachers' strikes and poor teaching deliveries by teachers even when they are in school [2]. With regard to enrolment in both public and private schools, Tooley et al., [3] estimated that around $25 \%$ of children were in government schools, $42 \%$ in approved private schools, and 33\% in unapproved private schools in this state.

The education of parents and the family income are two demographic characteristics which invariably show the student's social and family background [4]. This is because; students come from various socio-economic backgrounds into the school system to learn. There is also the perception that students in state owned schools, commonly called public schools, have low income parents/guardians thus validating a 'poverty of background'. This focus of this paper therefore is to measure the extent of impact of socio-economic profiling on students on their learning outcomes in the study area.

\section{Review of Literature}

\subsection{Students' socio-economic profile and academic performance}

Every student desire to be excellent and achieve high grades in school; this can be likened to the apex of the pyramid- self-actualization as shown in Maslow's hierarchy of needs in Fig.1. However, the lowest level of need is defined as physiological needs. 


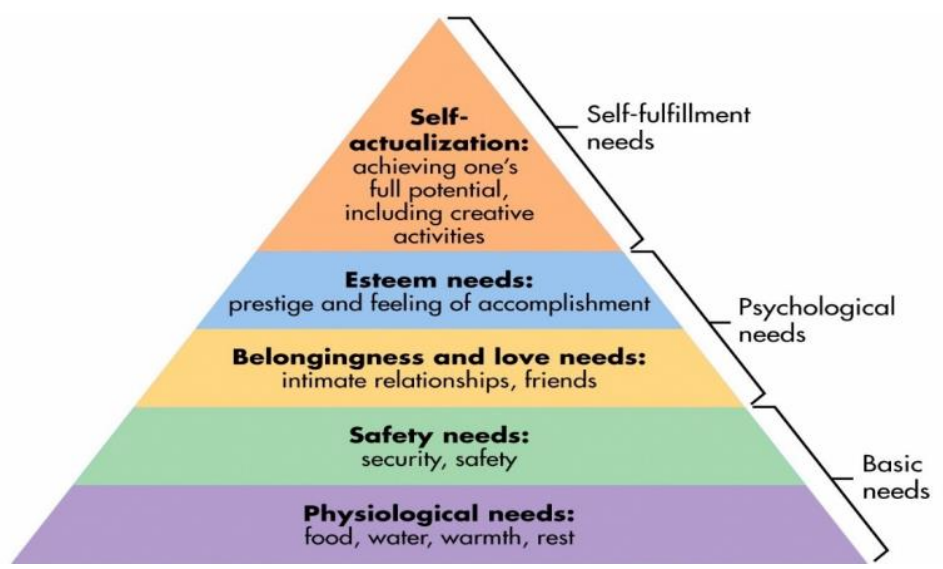

Fig. 1. Showing Maslow's hierarchy of needs [5]

Saenz and Pettyjohn [6] examined the underlying concept of Maslow's theory of motivation also known as the hierarchy of needs as shown in Figure 1. According to the theory, action and learning is based on one's position or level in the pyramid. The widest part of the pyramid is the least level, the bottom of the pyramid- the physiological needs such as food, water and shelter. The implication therefore is that, these basic needs must be met before ascension to the next level in the pyramid. Rest and warmth for example is a function of the quality of housing and residential accommodation of students. The same applies to safety and security; this is seen through their means of transportation to school. Their level of safety and security may differ if they trek on foot to school or commute through public transport or driven to school by private cars or even resident as boarders in school.

The relevance of the Maslow's theory of motivation in this paper is primarily hinged on its acknowledgement of the socio-economic characteristics articulated in the physiological needs and safety needs of students (gender, age, class, parent's education, residence type, transportation to school) and how they impact on students' learning outcomes in their respective classroom learning environment.

\subsection{Students' learning outcomes}

With regard to learning outcomes, many important outcomes of learning are not simply or quickly measurable. The impact of learning is not short lived; it is long term. The impact could result in outcomes that affect knowledge, skills, actions, feelings and emotions, ideas, affiliation to learning, a sense of oneself, a sense of others, and a sense of membership [7]. However, in the short term, certain rubrics can be used to measure learning outcomes. Examples include, class attendance, formative assessments and general engagement and interactions in class and learning activities. Student engagement is one of the outcomes from learning. Although it has been linked to cognitive skills, the amount of time and energy students put into their studies can contribute to their success [8]. The following indicators have been found to meas- 
ure students' learning outcomes. These can be further grouped into affective, behavioural \& cognitive indicators:

i. Student's academic achievement as measured by standardised test scores and exams coupled with teacher observation.

ii. Improved engagement in learning, interactions and teamwork.

iii. Wellbeing in terms of physical comfort, health, and sense of safety.

iv. Behavioural changes related to vandalism, absenteeism, suspensions, expulsions, disciplinary cases, violence, disruption in class, lateness to school [9].

This paper focuses on students' academic achievement as measured through grades and scores.

\subsection{Non-physical indicators for improving students' learning outcomes}

Asides the physical socio-economic indicators that can influence students' learning outcomes, research have shown that, there are other non-physical indicators for improving learning outcomes. These include mindset, motivation and interest. This becomes imperative in this context when blended with their physiological and socioeconomic profiling. In the works of Carol Dweck, it was affirmed that the selfactualisation of students is a function of their mindset. The study affirmed that, the different beliefs or mindsets formed by students create different psychological worlds. One of such worlds is the one that opines that ability is fixed; that a student's intelligence is fixed. The opposite opines that student's intellectual ability can grow [10]. These differing beliefs form the backbone behind a student's motivation and performance. In other words, a fixed mindset can prevent students from reaching the apex of that pyramid as shown in Figure 1, while a growth mindset can help students to achieve their learning outcomes.

Furthermore, a student's belief or mindset is formed from varying factors predominant amongst is the background from home. This can be seen in expression from the self-esteem of students. Although mindset is an internal wiring, it can be changed. Dweck opines that the use of right words, praises and affirmations that focus on the process, the efforts of students and not only the final results irrespective of background or socio-economic profiling can boost their esteem and motivation to learning [10]. Similarly, this was corroborated in the work of Loima et al., [11] that motivation and students' interest is a key state for any learning. Students' interest here could be connected with learning styles, what arouses a student to learn.

\section{Research Methods}

The data presented in this article is part of those used for a larger research work investigating the impact of classroom architecture on students' learning outcomes in selected secondary schools in Lagos State, Nigeria. The research design and approach used for the study was a cross-sectional survey and quantitative research similar to that of Papadakis (2018) in a survey to students [12]. 
The study population for this study comprised of all approved public and private secondary schools in Lagos State with focus on the senior secondary schools, with students predominantly late adolescents across the three senatorial districts in the study area namely: Lagos West, Lagos Central and Lagos East. The multi-stage sampling technique was adopted using a hybrid of three techniques: purposive sampling, quota and random sampling. The purposive sampling was based on the criterion that the selected schools must be approved with a senior secondary section. Next, for quota sampling, they were grouped in the three senatorial districts, dividing them into smaller units and afterwards applying a ratio based on the appearances. A ratio of 3:1 (private: public schools) is adopted based on proportion of private and public schools (1078 private senior secondary schools and 338 senior secondary schools), respectively.

The final school subjects were selected at random; three (3) private senior secondary schools and one (1) public senior secondary school per senatorial district following the ratio $3: 1$. The sample for the study was drawn from the population of the selected schools. The total number of students enrolled in the selected senior secondary private and public senior secondary schools gives a value of $\mathrm{N}=3291$. The sample size formulae on the one hand for finite population by Yamane in Singh et al., [13] for population above one hundred (100); this gives 3018. On the other hand, census is applied for population below one hundred (100).

$$
\begin{gathered}
N \\
n=1+N(e) 2
\end{gathered}
$$

where $\mathrm{N}=3018$; the total population size (for population above one hundred (100), $\mathrm{e}=$ the maximum acceptable error margin $(5 \%$ which gives $\mathrm{e}=0.05)$ and, $\mathrm{n}=$ the required sample size $=353$. Census is applied for population below one hundred (100); this gives a total sample size of 626.

A total of 674 copies of the questionnaire were administered physically by hand during the first term of the 2018/2019 academic session. A total of 488 were duly filled and useful for analysis, representing $72 \%$ of total administered. The questionnaire used was designed by the researchers and had five (5) sections A to E on different thematic foci. However, only data collected from sections A and B of the questionnaire were included in this paper. This covered socio-economic characteristics and learning styles. The data collected from the survey was analysed using the Statistical Package for the Social Sciences (SPSS) software package and presented in tables and charts.

\section{$4 \quad$ Results and Discussion}

The results from this study are hereby shown. Table 1 shows the socio-economic profiling of students in the study area. 
Table 1. Socio-Economic Profiling of Students in the Study Area

\begin{tabular}{|l|c|c|}
\hline \multicolumn{1}{|c|}{ Variables } & Frequency (n=488) & Percentage (\%) \\
\hline Male & 208 & 42.6 \\
\hline Female & 280 & 57.4 \\
\hline \multicolumn{3}{|c|}{ Age } \\
\hline Under 13 & 17 & 3.5 \\
\hline $13-15$ & 342 & 70.1 \\
\hline 16 - 18 & 123 & 25.5 \\
\hline 19 and above & 1 & 0.2 \\
\hline \multicolumn{3}{|c|}{ Class } \\
\hline SS 1 (Year 10) & 202 & 41.4 \\
\hline SS 2 (Year 11) & 176 & 36.1 \\
\hline SS 3 (Year 12) & 106 & 21.7 \\
\hline \multicolumn{3}{|c|}{ Residence Type } \\
\hline Duplex/Maisonette & 160 & 32.8 \\
\hline Bungalow & 87 & 17.8 \\
\hline Flat & 112 & 23.0 \\
\hline Mini-Flat / Self-Contain & 49 & 10.0 \\
\hline Rooming & 72 & 14.8 \\
\hline \multicolumn{2}{|c|}{ Transportation } \\
\hline School Bus & 58 & 11.9 \\
\hline Private Car & 104 & 21.4 \\
\hline Public Transport & 122 & 29.1 \\
\hline Trekking & 143 & 12.3 \\
\hline Boarders & 60 & \\
\hline
\end{tabular}

With reference to the socio-economic profile of students, Table I showed the gender spread, age range, classes, residence types and students' means of transportation to school. From the result, a higher proportion of students trek on foot to school while a quarter of the respondents' commute using public transportation. What possible implication could this have on their learning outcomes? A regression analysis was carried out to investigate this. The result showed a R2 value of $21.4 \%$ with significant impact on students' learning outcomes with $\mathrm{p}=0.01$. Table II shows the socioeconomic and physiological factors that have most significant impact on students' learning outcomes. 
Table 2. Coefficients of the Regression Analysis

\begin{tabular}{|l|c|c|c|c|c|}
\hline \multirow{4}{*}{} & Ctandardized Coefficients & \multirow{2}{*}{ Cf } & F & \multirow{2}{*}{ Sig. } \\
\cline { 2 - 5 } & Beta & $\begin{array}{c}\text { Bootstrap (1000) } \\
\text { Estimate of Std. Error }\end{array}$ & & & \\
\hline Gender & & .061 & 2 & .445 & .641 \\
\hline Age & -.041 & .084 & 2 & .310 & .734 \\
\hline Class & -.047 & .072 & 1 & 3.577 & .060 \\
\hline Selected School & -.136 & .249 & 2 & 2.734 & .067 \\
\hline Geographical Location of School & .412 & .122 & 3 & 4.852 & .003 \\
\hline Residence Type & .270 & .123 & 2 & .210 & .811 \\
\hline House Ownership & -.056 & .074 & 1 & 1.441 & .231 \\
\hline Means of Transportation to School &. .099 & .095 & 1 & 1.078 & .300 \\
\hline Type of School: Private or Public & .435 & .226 & 3 & 3.711 & .012 \\
\hline Learning Styles & .149 & .063 & 2 & 5.643 & .004 \\
\hline Dependent Variable: Learning Outcomes & & & & \\
\hline
\end{tabular}

Note: The items in bold letter are the significant variables at $\mathrm{P}<0.05$

Table 2 showed that, the most significant variable that influenced students' learning outcomes were the geographical location of the school, the type of school (either private or public) and students' learning styles. To further investigate the impact of the type of school on students' learning outcomes, a cross tabulation was used for a comparative analysis.

\section{Conclusion}

Findings from this study are congruent with Akareem and Hossain [4] who posited that, the education of parents and the family income are two demographic characteristics which invariably show the student's social and family background. Since students come from various socio-economic backgrounds into the school system, there is little or no control over this. The kind of house the students lived in, the ownership and the means of transportation to school are three (3) metrics pivotal to showing the student's social and family background as found from this study. This study has also found that the geographical location of the school, type of school and learning styles of students has more significance impact on students' learning outcomes. This therefore takes preference over gender, age, class, residence type, ownership of house or even the means of transport to school. However, the study revealed a diverging performance of students, as students in private schools performed academically than those in public schools. From the literature reviewed, this can be as a result of a differing level of mindset, motivation and interest of students, teachers and administrators in both private and public schools. Other factors investigated by [14] - [16] such as quality of classroom learning environment, school maintenance and other adjoining school factors could be precursors to the diverging performance of students in private and public schools. In another view, a study on parental involvement on children's digital learning affirmed that, parents have a positive outlook towards their children's learning even with the use of mobile devices and specifically that, this attitude is not 
different from parents of varying economic and social characteristics[17]. Summarily, this study has identified that geographical location of a school, the type of the school and students' learning styles are key socio-economic characteristics that impacts significantly on students' learning outcomes.

This paper further recommends that, instilling internal motivation in students irrespective of their economic outlook can boost their self-esteem and self-actualisation in line with Carol Dweck's position. Irrespective of the economic outlook, more efforts should be placed at helping students to have a strong internal motivation that surpasses external motivations since external motivation is mostly boosted by awards, rewards and parents' financial wherewithal. This will in turn influence students' mindset, a non-physical indicator for improving students' learning outcomes. In the same vein, Owoseni et al.,[18] suggests that internal motivation can be achieved by helping students understand why they are in school in the first place; reminding them of the reason behind the season of their schooling. With this in mind, students will have a positive motivation, own their learning and work towards their selfactualisation amidst their respective socio-economic background.

\subsection{Abbreviations and Acronyms}

- SUBEB - State Universal Basic Education Board

- LGEA - Local Government Education Authority

\section{Acknowledgement}

The authors would like to appreciate Covenant University Centre for Research, Innovation and Discovery (CUCRID) for the support for this publication and the sampled schools for the opportunity to undertake this study in their respective schools.

\section{$7 \quad$ References}

[1] National Bureau of Statistics NBS (2016). Annual Abstract of Statistics 1:152. Retrieved 17 September 2017, from National Bureau of Statistics: https://nigerianstat.gov.ng/ download/590

[2] Harma, J. (n.d.). Private Responses to State Failure: The Growth in Private Education (And Why) In Lagos, Nigeria. Retrieved on 28 September 2017, from The National Center for the Study of Privatization in Education: http://ncspe.tc.columbia.edu/workingpapers/OP215.pdf

[3] Tooley, J., Dixon, P., \& Olaniyan, O. (2005). Private and public schooling in low-income areas of Lagos State, Nigeria: A census and comparative survey. International Journal of Educational Research, 43(3), 125-146. https://doi.org/10.1016/j.ijer.2006.05.001

[4] Akareem, H. S., \& Hossain, S. S. (2016). Determinants of education quality: what makes students' perception different? Open Review of Educational Research, 3(1), 52-67. https://doi.org/10.1080/23265507.2016.1155167 
[5] Demetriou D. (2016) Maslow's Amazing Hierarchy of Needs. Retrieved on 23 March 2018, from UNICAF: https://www.unicaf.org/maslows-amazing-hierarchy-of-needs/

[6] Saenz \& Pettyjohn (2011). The impact of the environment: Maslow's theory of motivation (1943). Retrieved on 10 June 2020, from Learning Wales: http://learning.gov.wales/resou rces/learningpacks/mep/special-educational-needs-and-inclusion/impact-of-the-environme nt/maslows-theory-of-motivation/?lang=en.

[7] Watkins C., Carnell E., Lodge C, Wagner P. \&Whalley C. (2002) Effective Learning. Retrieved on 3 June 2020, from:

https://www.researchgate.net/publication/320195027_Effective_Learning. https://doi.org/10.4324/9780203991886

[8] Miller, R. L., \& Butler, J. M. (2011). Outcomes associated with student engagement. Promoting student engagement, 1 . Retrieved on 2 June 2020, from http://stp.wildapricot.org/Resources/Documents/ebooks/pse2011vol1.pdf\#page=23

[9] [Blackmore, J., Bateman, D., O’Mara, J., Loughlin, J., \& Aranda, G. (2011). The connections between learning spaces and learning outcomes: People and learning places. Retrieved 12 March 2020, from Learning Spaces: http://www.learningspaces.edu.au/docs/learningspaces-final-report.pdf

[10] Dweck, C. S. (2008). Brainology: Transforming students' motivation to learn. Independent School, 67(2), 110-119.

[11] Loima, J., \& Vibulphol, J. (2014). Internal Interest or External Performing? A Qualitative Study on Motivation and Learning of 9th Graders in Thailand Basic Education. Journal of Education and Learning, 3(3), 194-203. https://doi.org/10.5539/jel.v3n3p194

[12] Papadakis, S. (2018). Evaluating pre-service teachers' acceptance of mobile devices with regards to their age and gender: a case study in Greece. International Journal of Mobile Learning and Organisation IJMLO, 12(4), 336-352. https://doi.org/10.1504/ijmlo.2018.10 $\underline{013372}$

[13] Singh, A. S., \& Masuku, M. B. (2014). Sampling techniques \& determination of sample size in applied statistics research: An overview. International Journal of Economics, Commerce and Management, 2(11), 1-22.

[14] Ibem E., Alagbe O., Owoseni A. (2017). A Study of Students' Perception of the Learning Environment: Case Study of Department of Architecture, Covenant University, Ota Ogun State, Inted2017 Proceedings, 6275-6286. https://doi.org/10.21125/inted.2017.1455

[15] Obayan, P. T. (2003). Realizing Nigerian millennium education dream. The UBE in O. Bamisaiye, Nwazuoke and Okediran (eds). Education this Millennium, Ibadan.

[16] Izobo-Martins, O., Dare-Abel, O. A., \& Ayo-Vaughan, K. (2014). Infrastructure Conditions in Public Secondary Schools, Ogun State, Nigeria. Journal of Civil, Structural, Environmental and Infrastructure Engineering Research and Development, 4(5): 17-25.

[17] Papadakis, S., Zaranis, N., \& Kalogiannakis, M. (2019). Parental involvement and attitudes towards young Greek children's mobile usage. International Journal of Child-Computer Interaction, 22, 100144. https://doi.org/10.1016/j.ijcci.2019.100144

[18] Owoseni, A., Odukoya, J. A., \& Ekhaese, E. N. (2018). A Reflection on the Purpose of Schooling: A Survey of Nigerian Students and Graduates. EDULEARN18 Proceedings, pp. 337-346. https://doi.org/10.21125/edulearn.2018.0160 


\section{Authors}

Owoseni, A.O. is a renowned authority on youth development with a background in Architecture. Since 2011, Abraham has been on a life mission of raising young people and moulding minds. He is passionate about adolescent development, life skills education, remodeling learning environments and building development centres for young people for their holistic development. http://www.abrahamowoseni.com/

Ibem, E.O. is a chartered Architect and a Professor of Architecture. He is an established researcher in sustainable housing and urban development, post-occupancy evaluation (POE) and electronic procurement in architecture and construction. He has over 60 scholarly publications in ISI- listed and SCOPUS-indexed international journals, referred conference proceedings and books.

Opoko A.P. is an Associate Professor at the Department of Architecture, Covenant University. She is also a fellow of the Strategic Institute for Natural Resources and Human Development. She has served as the president, Female Architects of Nigeria (FAN) with several other recognitions.

Article submitted 2020-04-06. Resubmitted 2020-05-14. Final acceptance 2020-06-05. Final version published as submitted by the authors. 